DOI https://doi.org/10.18551/rjoas.2017-08.30

\title{
THE EFFECT OF DRYING METHOD AND TYPES OF NATURAL FIXATIVE ON THE COIR OF KELAPA GADING (COCOS NUCIFERA EBURNEA) TOWARD COLOR INTENSITY AND COLOR DURABILITY OF BATIK CLOTH
}

\author{
Dewanti Beauty Suestining Diah*, Wijana Susinggih, Hapsari Ravenska Narendra \\ Department of Industrial Technology of Agriculture, Faculty of Agricultural Technology, \\ University of Brawijaya, Indonesia \\ *E-mail: beauty dewanti@yahoo.com
}

\begin{abstract}
The purpose of this study is to know the effect of drying method of Kelapa Gading fiber or coir, and fixation material toward color intensity and color durability in batik cloth by using natural colorant. The study uses Factorial Randomized Block Design (FRBD). The first factor is the method of drying the fiber, i.e. sun drying and wind drying. The second factor is the type of fixation materials that is alum, quicklime (calcium oxide), and iron or tunjung. The best treatment result using Multiple Attribute method is sun drying with quicklime $(\mathrm{CaO})$ fixator on the concentration of $15 \%(\mathrm{w} / \mathrm{v})$. Color intensity value that is brightness $\mathrm{L}^{*} 46.8, \mathrm{a}^{*}$ value (red color intensity) 24.13 and $b^{*}$ value (yellow color intensity) 16.93; the color difference is 13.6 which means a big influence exists. The dryness and wetness test shows SS (Staining Scale) value of 4 (good) and 4 (good). The color durability test for shows SS value of 4-5 (good) and GS (Gray Scale) value of 4 (good). The result of color intensity test of $L^{*}$ indicates that the alum fixator can bind $L^{*}$ (brightness level) more strongly. Quicklime fixator is capable of binding the value of $a^{*}$ (red color) and $b^{*}$ (yellow color) more strongly. The fixation material of iron produces weaker $L^{*}, a^{*}$ and $b^{*}$ values. The sun dried coir of Kelapa Gading binds more red $\left(a^{*}\right)$ and yellow $\left(b^{*}\right)$ color. The longer the drying time, the higher the oxidation process and the higher the tannin content which makes the product more damaged.
\end{abstract}

\section{KEY WORDS}

Fixation, color, durability, intensity, drying, Kelapa Gading fiber.

Batik craft in Indonesia has been growing rapidly, in technique, technology, and development of related motives and cultures. Based on data from the Ministry of Industry (2014), since 2011 to 2015 , batik industry has grown $14.7 \%$ from 41,623 units to 47,755 units of batik business. Batik was previously only known in the palace environment in Java and was made with hand-made system whereas the dyes used were all coming from nature both plants and animals (Atikasari, 2005).

Batik industry generally uses synthetic dyes in the process of dyeing batik cloth, but some use natural dyes. According to Kristijanto and Hartati (2013), synthetic dyes generally have a fixed composition, with brighter coloration results, good color intensity, more color durability, and contain heavy metals not easily degraded, which can pollute the environment and have a direct impact on health for humans. Natural dyes for textile can be produced from plant extracts such as roots, stems, leaves, skins, flowers and seeds, and natural dyes are more easily degraded (Aliya, 2010).

Examples of natural dye substances are chlorophyll, carotenoid, anthocyanin, and tannin. The substances have distinctive colors difficult to be imitated by synthetic dyes. Natural colorant is environmentally friendly and non-toxic. One of the plants containing natural dyes or colorant that has not been used much for textile industry is Kelapa Gading. The part of coconut that can be extracted as natural colorant is the fiber or coir. According to Sari et al. (2005), coir can be used as a natural dye because it contains tannins of the flavonoid group - when it is soaked in water, it will result in reddish brown color. The downside of natural coloring is the need of fixation to lock the color as to avoid fading; some materials used in fixation include alum, lime, and iron (Palupi, 2015). 
Dried coir is generally used as fuel, board, and briquettes. It has not been used much as a raw material for natural dyes. Coir drying can be done under the sun, wind, or using special dryer. Drying temperature and time will affect the levels of tannin and will cause browning due to enzyme activity (Astutik, 2008). The higher the temperature and the long the drying process, then the higher the oxidation process and the content of tannins will be.

Fixation is the most important stage in the process of batik coloring. Fixation changes the color of natural substances in accordance with the type of metal binding it; fixation helps to lock the color entering the fiber (Agoes, 2007). The materials used for the fixation is alum, lime $(\mathrm{CaO})$ and iron $\left(\mathrm{FeSO}_{4}\right)$.

\section{MATERIALS AND METHODS OF RESEARCH}

The tools used for preliminary research among others are trays, pans, stoves, thermometers, measuring cup, digital scales, mixer, filter, screen cloth, scissors, glue, hairdryer, staplers, boards, brushes, and plankan. Tools for the test include Laundry meter, Crock meter, Grey Scale, and the Staining Scale. The materials used include coir of Kelapa Gading, wax, primissima cloth, wax, and water as a solvent. Fixation materials used are alum, lime ( $\mathrm{CaO})$, and iron (FeSO4). as follows:

The study uses Factorial Randomized Block Design (FRBD), consisting of two factors,

The first factor $(A)$ is the method of coir drying:

$A_{1}$ : Sun drying

$A_{2}$ : Wind drying

The second factor $(B)$ is the fixation material:

$B_{1:}$ Alum $15 \%$

$\mathrm{B}_{2}$ : Lime $15 \%$

$B_{3}$ : Iron $15 \%$

The process in drying coir of Kelapa Gading is as follows:

- $1 \mathrm{~kg}$ of coir is cut into small pieces of $10 \mathrm{~cm}$;

- the pieces of coir are arranged on the trays;

- the pieces of coir are divided into two-the first half for sun drying for 5 days (8 hours/day, from 08:00 to 15:00) and the second half for wind drying for 7 days;

- the dried pieces of coir is scaled; and

- the dried coir is ready.

The fixation process of the dried coir is as follows:

- dry cloth is soaked into the natural dye solution as many as 15 times;

- the dried batik cloth goes through fixation (using alum, lime, and iron);

- wax removing (nglorod) is done on the batik cloth; and

- last step is to wash and dry the batik cloth.

Observations made include a test on color durability and color intensity. The test on color durability is against rubbing (SNI 0288-2008) and against leaching (SNI ISO 105C06:2010). The selection on the best alternative uses Multiple Attribute (Zelleny, 1982).

\section{RESULTS AND DISCUSSION}

Test on $a^{*}$ Value. The results of the analysis of variance shows different methods of drying brings significant influence. The different types of fixatives show significant influence against $a^{*}$; thus, a DMRT at the level of significance of $5 \%$ on each factor must be done. The results of DMRT are presented in Table 1.

Tabel 1. The Effect of Different Drying Methods and Fixatives toward the Average Value of $a^{*}$ on the Batik Cloth Produced

\begin{tabular}{lll}
\hline \multicolumn{2}{l}{ Treatment } & $\begin{array}{l}\text { Average } \\
\text { Value of }\end{array}$ JNT Notation \\
\hline
\end{tabular}




\begin{tabular}{lllll}
\hline Method & & $\mathbf{a}^{*}$ & & \\
\hline Sun & Alum & 21.47 & 0.57 & $\mathrm{~d}$ \\
& Lime & 24.13 & 0.76 & $\mathrm{f}$ \\
& Iron & 11.83 & 0.49 & $\mathrm{a}$ \\
Wind & Alum & 20.80 & 0.53 & $\mathrm{c}$ \\
& Lime & 22.13 & 0.63 & $\mathrm{~b}$ \\
& Iron & 13.20 & 0.51 & $\mathrm{e}$ \\
\hline
\end{tabular}

Note: Different notations show significant difference of treatment based on DMRT at significance level of $5 \%$

Table 1 shows different drying method, and different fixatives bring significant difference in the batik cloth produced; the different notations on each factor show this. The highest $a^{*}$ value is for lime, followed by alum and iron. Lime produces the highest $a^{*}$ value for both sun and wind drying. This shows that lime as fixative produces the best red color, for both drying methods, compared to alum and iron as fixatives. According to Failisnur and Sofyan, (2014) $\mathrm{Ca}^{2+}$ ions form bigger molecules inside the pores of coir creating redder color, tending to be darker. The color occurs due to the ionic reaction between tannins (tannic acid) and $\mathrm{Ca}^{2+}$ ions in lime.

Alum $\left(\mathrm{Al}_{2}\left(\mathrm{SO}_{4}\right)_{3}\right)$ produces a color similar to the original one or golden yellow. This happens because of ionic reactions between tannins (tannic acid) with $\mathrm{Al}^{3+}$ ions and iron $\left(\mathrm{FeSO}_{4}\right)$, especially $\mathrm{Fe}^{+}$ions, forming green to dark green color that produces a complex salt (ferrous tanat). The complex salts are formed by the presence of covalent coordination between metal ions with non-metal ions (Taofik et al., 2010).

Sun drying with lime fixative produces higher red color intensity compared to wind drying. This is affected by the drying of extracts-the higher the temperature and the longer the drying process, the higher the oxidation and the tannin content, leading to change in color. Formation of brown color is caused the phenolic compounds induced in coir, which acts as a substrate in the process of enzymatic browning. According to Rahmawati (2008), browning is the process of formation of yellow pigment instantly transformed into dark brown. Browning is influenced by the activity of polyphenols oxidase enzyme with the help of oxygen to change the cluster mono phenol became O-hydroxyl phenols, which further modified again into O-Quinones. This cluster of O-Quinones forms brown color. Changes that occur during drying are hydrolysis enzymatic, accompanied by a change of color and aroma due to the enzyme activity, polymerization, and oxidation (Manoi, 2006).

Test on $b^{*}$ Value. The average values of $b^{*}$ produced in color intensity test of coir with different methods of drying and fixatives is 12.77 to 16.93 . Different methods of drying and different fixatives bring significant difference. Interaction of both brings significant difference. The highest value of $b^{*}$ is for lime, followed by alum and iron. Sun drying with lime as fixative indicates the highest value of $b^{*}$ compared with wind drying. The average value of $b^{*}$ can be seen in Table 2.

Table 2 - The Effect of Different Drying Methods and Fixatives toward the Average Value of $b^{*}$

\begin{tabular}{|c|c|c|c|c|}
\hline \multicolumn{2}{|c|}{ Treatment } & \multirow{2}{*}{ Average Value of $b^{*}$} & \multirow[b]{2}{*}{ JNT } & \multirow[b]{2}{*}{ Notatior } \\
\hline Drying Method & Fixatives & & & \\
\hline \multirow{3}{*}{ Sun } & Alum & 16.43 & 1 & C \\
\hline & Lime & 16.93 & 0.84 & $d$ \\
\hline & Iron & 12.77 & 0.66 & a \\
\hline \multirow{3}{*}{ Wind } & Alum & 13.77 & 0.68 & $a$ \\
\hline & Lime & 15.43 & 0.76 & c \\
\hline & Iron & 14.33 & 0.71 & $b$ \\
\hline
\end{tabular}

Note: Different notations show significant difference of treatment based on DMRT at significance level of $5 \%$. 
The value of $b^{*}$ shows significant difference on the different methods of drying as there is a difference in the ability of coir to absorb the color of natural colorant, and also a difference in fixatives. This is because the drying method affects the color of the extract absorbed by coir. Lime binds a lot of yellow pigment on the coir. According to Kristijanto and Soetjipto (2013), tannin with $\mathrm{Ca}^{2+}$ ion in lime will produce yellow pigment. $\mathrm{CaO}$ is able to form a stronger yellow pigment compared with alum $\left(\mathrm{Al}_{2}\left(\mathrm{SO}_{4}\right)_{3}\right)$ and iron $\left(\mathrm{FeSO}_{4}\right)$ which is unable to form yellow pigment.

According to Fitrihana (2011), alum serves to retain the original color of the natural colorant and to lock it during staining. Iron serves to produce darker color due to the formation of complex salts by $\mathrm{Fe}^{2+}$ ions. Complex salt (ferrous tanat) is formed due to the covalent bond between the metal ions and non-metal ions that produce the blackish green color (Taofik et al., 2010).

The brown color on the coir will get darken due to the oxidation reaction of the phenol enzyme with the substrate of the materials in the browning process. The intensity of yellow color is also triggered by the lime fixation due to ionic reaction of $\mathrm{Ca}^{2+}$ with tannin (tannic acid) which produces more yellow pigment.

The formation of brown color is triggered by oxidase reactions catalyzed by the phenol oxidase or polyphenol oxidase enzyme. Both enzymes can catalyze the oxidation of phenol compounds into Quinone and then polymerized into a brown melanin pigment (Mardiah, 1996).

Test on $L^{*}$ Value. The result of variance analysis shows that the average value of $L^{*}$ (bright and dark level with a range of 0-100) treatment with different methods of drying and fixatives from 22.16 until 27.65. Different methods of drying and different fixatives bring significant difference toward $L^{*}$ value. Their interactions show no significant difference. The effect of different fixatives can be seen in Table 3.

Table 3 - The Effect of Different Drying Methods and Fixatives toward the Average Value of $L^{*}$

\begin{tabular}{|c|c|c|c|c|c|}
\hline \multicolumn{2}{|c|}{ Fixatives } & $\begin{array}{l}\text { Alum } \\
27.65\end{array}$ & $\begin{array}{l}\text { Lime } \\
23.86\end{array}$ & $\begin{array}{c}\text { Iron } \\
22.16\end{array}$ & Notation \\
\hline Alum & 27.65 & & 3.79 & 5.49 & $a$ \\
\hline Lime & 23.86 & & & 1.7 & b \\
\hline Iron & 22.16 & & & & $c$ \\
\hline
\end{tabular}

Note: Different notations show significant difference of treatment based on DMRT at significance level of $5 \%$.

Table 3 shows the mean value of BNT test on different types of fixatives - all show a significant difference. According to Pomeranz and Meloans (1994), the $L^{*}$ values indicate the direction of bright and dark color, where 0 denotes a black or very dark tendency and 100 denotes a bright or tendency toward white. The alum fixator produces the brightest color direction with the $L^{*}$ value of 27.65 when compared to the lime and iron. This is due to the reaction of $\mathrm{Al}^{3+}$ ions in alum to tannin (tannic acid), where alum $\left(\mathrm{Al}_{2}\left(\mathrm{SO}_{4}\right)_{3}\right)$ has a valence 3 so it can bind 3 dye molecules (Sasas et al., 2000). Iron produces darker shades, this is because tannins containing phenol groups have $\mathrm{OH}$ groups that bind to form complex compounds with metals. The complex salts are formed by the presence of covalent bonds of metal ions with non-metal ions resulting in a greenish brown color (Yusmeiarti, 2007). Tannins that react with $\mathrm{CaO}$ and ferrous sulfate will become unstable resulting in brownish color intensity in lime and blackish greenish in iron. The color intensity decreases due to damage to the active group of the dye pigment resulting in bleaching. The high brightness level indicates the fading color of the extract, and the vice versa, low brightness indicates high color duration (Saati, 2004).

Lime produces darker color than alum does because $\mathrm{Ca}^{2+}$ ions form larger molecules in the pore of the fibers so the color becomes darker or reddish. The color occurs because of the ionic reactions between tannins (tannic acid) and $\mathrm{Ca}^{2+}$ ions in lime (Failisnur and Sofyan, 2014). Tannins that react with $\mathrm{CaO}$ and ferrous sulfate will become unstable resulting in brownish color intensity in lime and blackish greenish in iron. The color intensity decreases 
due to damage to the active group of the dye pigment resulting in bleaching. In general, drying duration (sun drying) affects the stability of dye (Rini and Kasmurdjo, 2006).

Test on Color Durability against Rubbing. The test results on the type of drying method and the types of fixatives show Color Different (CD) values ranging from 4 to 5.87 . In primissima cloth with sun drying method, the lowest Color Different (CD) value is for lime (4.53), and if converted to SS (Staining Scale) then the value is 4 (good). Figure 1 shows the results of color durability against dry rub test.

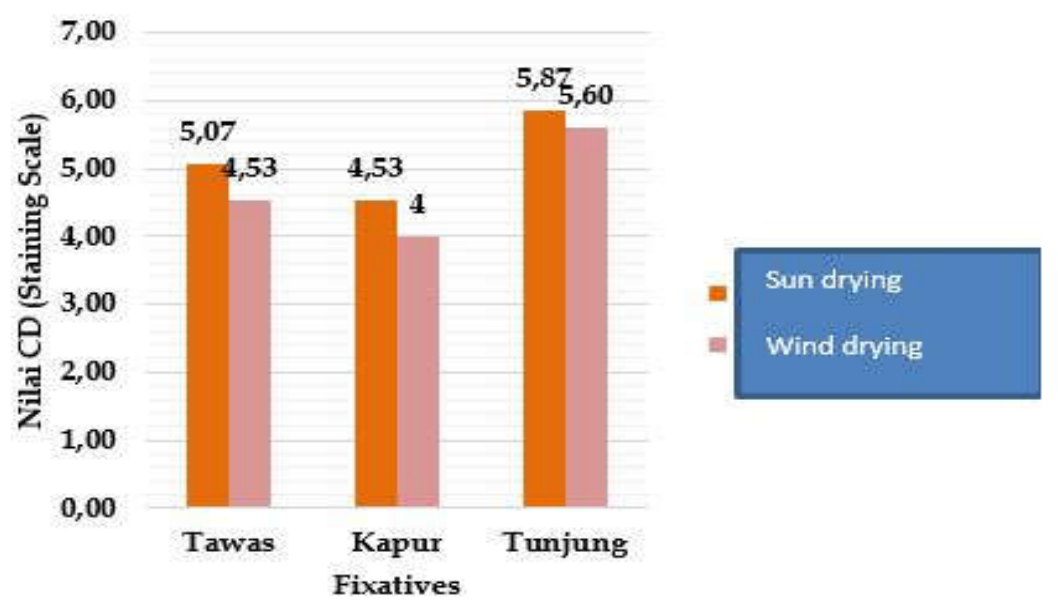

Figure 1 - The Average Value for Dry Rub

Figure 1 shows that iron as fixative shows the highest $C D$ value, for both sun drying and wind drying. The lower CD value affects color durability against dry rub. According to Moerdoko et al. (1975), the lower the value of CD, the better the color durability will be. The lowest value of $C D$ is for lime. According to Sulaeman (2000), the presence of $\mathrm{Ca}^{2+}$ ions from lime solution or $\mathrm{Al}^{3+}$ ions from the alum solution will create bond with tannin in coir making the molecule inside the natural dye bigger. According to Farida et al. (2011), with the addition of fixatives (alum, lime, or iron), tannins will not be released in the fibers and cause a change in the direction of the color according to fixatives.

Wind drying shows better color durability than sun drying, as sun-dried coir has the most concentrated color so natural dye is only attached to the surface of the fabric. At the time of dry rub test, the dye on batik cloth more easily comes out and leaves stain on the test cloth. According to Atikasari (2005), the breaking of the bond between the fabric and the auxochrome leads to low color durability, as cloth or fabric loses its ability to absorb color.

The intensity of sunlight affects the speed of water evaporation on coir and the extracted tannin compound in coir will be darker than wind drying. Wind drying causes coir to get less light, making the process of enzymatic browning on the material is shorter. The changes that occur during drying are enzymatic hydrolysis, browning with changes in color and aroma and enzyme activity, oxidation, and polymerization (Manoi, 2006). According to Rahmawati (2008), oxidation reaction and catalyze by phenol oxidase or polyphenol oxidase enzyme affects the formation of brown color.

Color Durability against Wet Rub Test. The test result on primissima cloth on color durability against wet rub shows CD (Color Different) value from 3.33 to 10.20. Lime with wind drying method shows the lowest CD value of 3.33, if converted to SS (Staining Scale) value, it equals to 4 (good). The results of wet rub indicate the presence of poor color durability, this is indicated by the greater value of the CD. Figure 2 shows the results of color durability against wet rub test.

Wet rub shows that natural dye of coir can adhere to the surface of plain white primissima cloth. Sun drying shows higher pattern compared with wind drying. The durability of fabric may reduce in wet rub, as according to Herlina (2007), the presence of water in wet 
rub test will cause the bulking of fibers, and molecules of natural dye will be carried by water, making the color to easily fade.

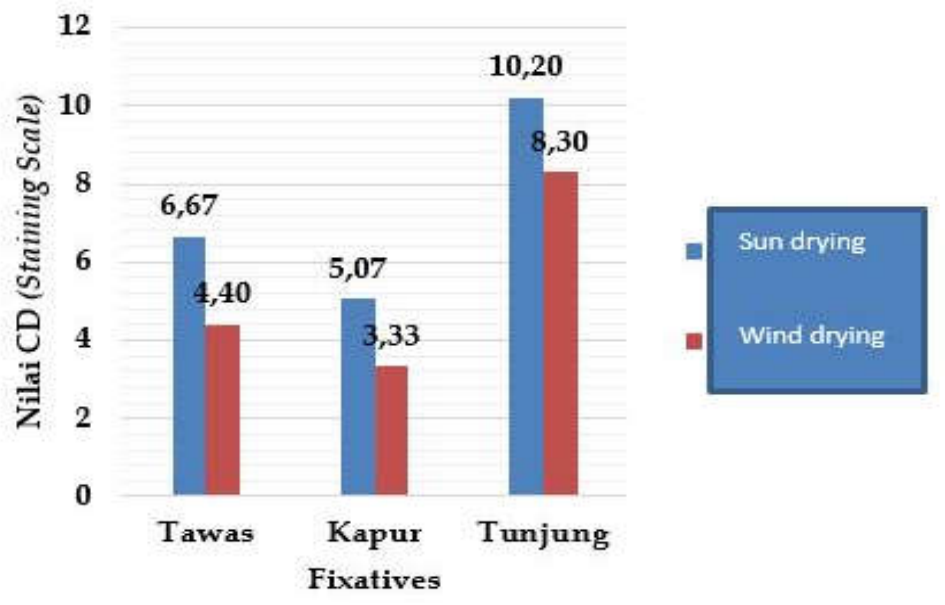

Figure 2 - The Average Value for Wet Rub

The less ability of dye materials to enter the fiber is due to the broken bond between the auxochrome fibers so the fabric loses its ability to absorb color and this makes the dye only attached to the surface of the fabric (Atikasari, 2005). Drying of coir also affects color durability of batik cloth. Good color durability is caused because the dye extracted from the wind drying can be well absorbed by the fabric fiber. The heat energy that attacks the dye molecule can break the dye molecule chain causing the color to fade (Taofik et al., 2010).

Test on Color Durability against Washing. The test result on primissima cloth on color durability against washing shows CD (Color Different) value between 5.87 to to 1.33. Lime with wind drying method shows the lowest CD value of 1.33, if converted to SS (Staining Scale) value, it equals to 4-5 (good). Figure 3 shows the results of color durability against washing test.

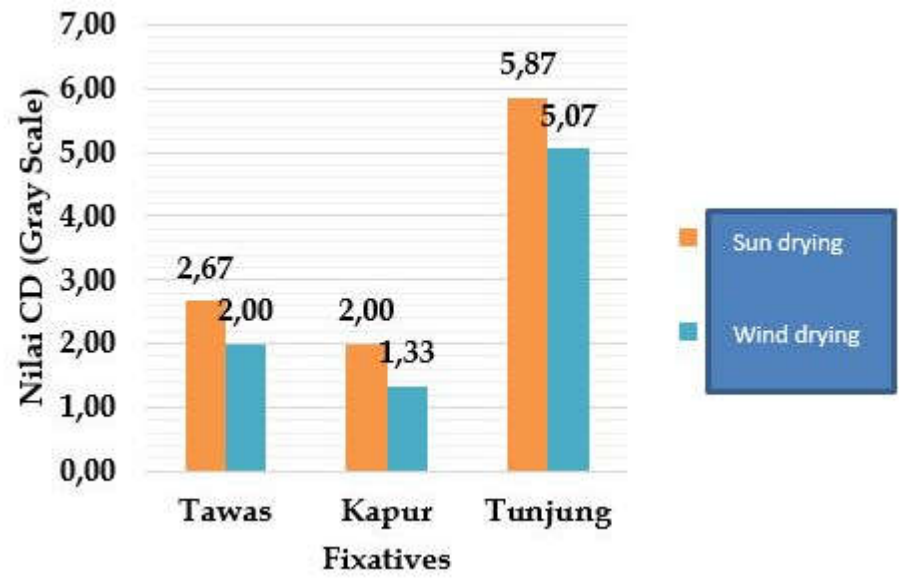

Figure 3 - The Average Value of Staining Scale

The results in Figure 3 with different methods of drying and different fixatives show that lime has the highest CD value (5); the higher the CD value, the better the color durability will be. This is because lime as fixative is able to bind the dye. Hasanudin and Widjiati (2002) state that the bond between the cloth fiber and dyestuff determines color durability. Test of textile materials soaked in soap solution undergoing mechanical movements show that chemicals and mechanical motions will bind the color of textile materials. If the bond between the dye and the cloth fiber is strong, then the color will not easily fade. Higher CD values 
indicate poor color durability. Iron is unable to hold or bind the dye in the cloth fiber so the dye molecule leaves the cloth surface easily.

The drying factor of coir also affect the color durability against washing, in which sun drying has a more intense brown color than wind drying. This is because the temperature in sun drying is higher making the tannin level and oxidation process higher. The higher the tannin makes the color will be more concentrated, but the color durability against washing is better for wind drying than sun drying. According to Wiley-Blackwell (2012), enzymatic browning reaction is responsible for the colors and aroma formed on the dryers.

Gray Scale. The results of primissima cloth test on the color change with different drying method and different fixatives show the lowest $C D$ value on alum that is 1.50 and 1.27 with GS value 4-5 (good). The color durability level against washing is presented in Figure 4.

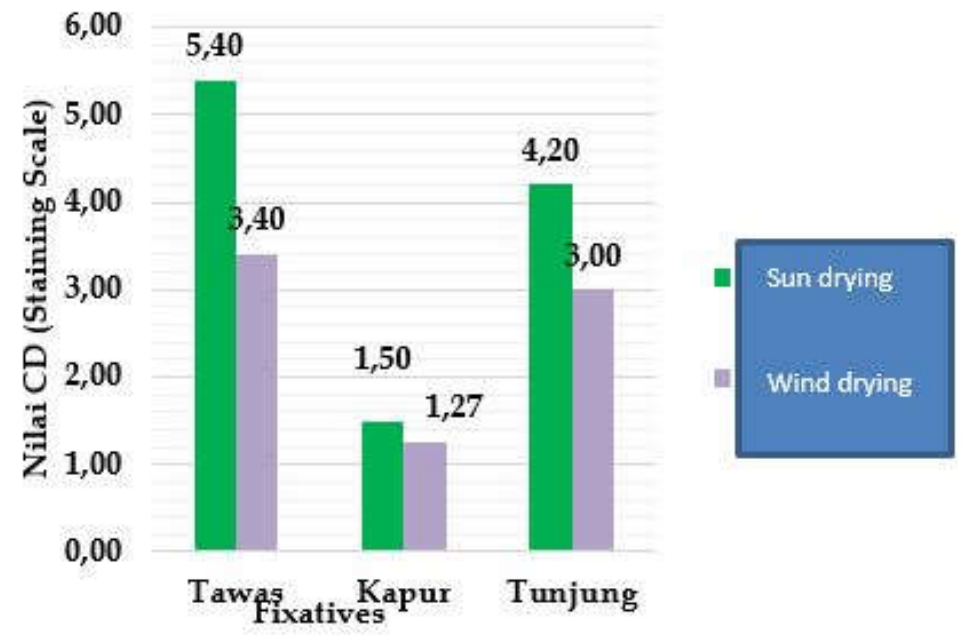

Figure 4 - The Average Value of Gray Scale

Batik cloth fixated by alum cannot survive in alkaline condition (washing), the value of color durability against washing is low. Lime and iron are able to survive in an alkaline atmosphere so color durability against washing is higher.

Herlina (2007) states that the result of fixation is minimal with a CD value of 3.00 . Washing using $\mathrm{Na}_{2} \mathrm{CO}_{3}$ and teepol makes the fabric undergo a different color change compared with the fabric without washing. The results of color durability of sun-dried and wind-dried coir show the same value for lime. This is influenced by the $\mathrm{pH}$ of the alum, lime, and iron which reacts with the detergent in the washing process. Tawas has an acid $\mathrm{pH}$, lime has an alkaline $\mathrm{pH}$, and iron has an alkaline $\mathrm{pH}$, whereas $\mathrm{Na}_{2} \mathrm{CO}_{3}$ has an alkaline $\mathrm{pH}$ included in the salt base type. This causes a change in the color direction to becomedarker than before the washing test.

The color of coir extract from sun drying is not concentrated or light brown because of the lower intensity of light and drying temperature making lower tannin level. According to Manoi (2006), the longer the drying time, the higher the tannin and oxidation process to make the resulting product experience browning with the change of color, aroma, enzyme activity, oxidation, and polymerization.

The Best Treatment. The best fabric resulted from coloring using coir of Kelapa Gading, done with Multiple Attribute, is batik cloth with sun drying and lime as fixative. The best treatment results based on the color intensity can be seen in Table 4 . The best treatment results based on color durability can be seen in Table 5 .

The best treatment results show color different value of 13.6 between the treatment using sun drying and lime as fixative with control treatment (sun drying without fixative)-this shows significant difference toward color intensity. $L^{*}$ value for sun drying and lime as fixatiive resulting in darker color is 46.8 , and 56.8 for control treatment of lighter color. The $a^{*}$ value for sun drying with lime as fixative results in higher red intensity of 24.13 , and 21.1 for control treatment. The $b^{*}$ value for sun drying with lime as fixative is 16.93 , and 16.1 for 
control treatment. This is because lime as fixative binds more dye compared to the control treatment. This is also due to higher tannin content due to browning in sun drying process. Enzymatic browning makes the color becomes darker or dark brown. This is in line with the statement by Alreza (2012) that phenolic compound can become a substrate in enzymatic browning. The browning in coir is triggered by oxidation process of phenolic compound to become Quinone of brown color.

Table 4 - The Best Treatment Results based on the Color Intensity

\begin{tabular}{cccc}
\hline \multirow{2}{*}{ Parameter } & \multicolumn{2}{c}{ Treatment } & Color Different \\
\cline { 2 - 3 } & Sun drying and lime as fixative & Control & $(\Delta \mathrm{E})$ \\
\hline $\mathrm{L}^{*}$ Value & 46.8 & 56.8 & 13.6 \\
$\mathrm{a}^{*}$ Value & 24.13 & 21.1 & \\
$\mathrm{~b}^{*}$ Value & 16.93 & 16.1 & \\
\hline
\end{tabular}

Table 5 - The Best Treatment Results and Control (Without Fixatives)

\begin{tabular}{ccc}
\hline \multirow{2}{*}{ Parameter } & \multicolumn{1}{c}{ Treatment } & No Fixatives \\
\cline { 2 - 3 } & Fixatives (Lime / Wind drying) (A2B2) & 5.86 \\
Dry rub & 4 & 7.2 \\
Wet rub & 3.3 & 5.8 \\
Staining Scale (SS) & 1.3 & 4.8 \\
Gray Scale (GS) & 1.27 & \\
\hline
\end{tabular}

Treatment results are compared with control treatment (no fixation). The dry rub test for wind drying and lime as fixative with control treatment has a difference of 1.86 , the wet rub test has a difference of 3.9 , the washing test against color staining (SS) has a difference of 4.5 and color change has a difference of 3.5. The best treatment result shows that the CD value for control treatment is greater than that wind drying and lime as fixative. This is presumed that in the control treatment, the molecules of substances absorbed by the fabric are more easily leaving the pores of fabric resulting from chemicals and mechanical movement during the washing test against color change and color staining. Herlina (2007) states that the result of fixation is minimal with a CD value of 3.00 .

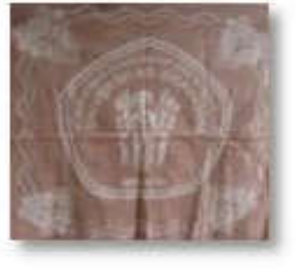

No Fixatives

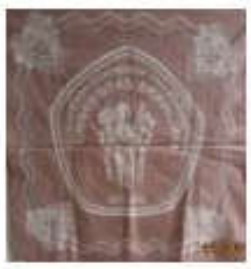

Lime

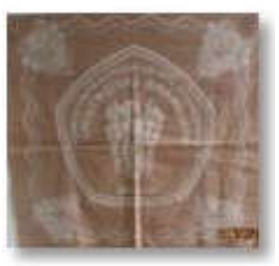

Alum

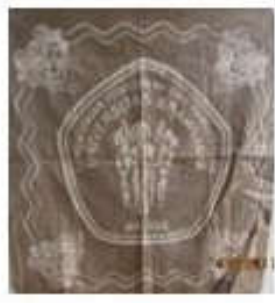

Iron

Figure 5 - Sun Drying

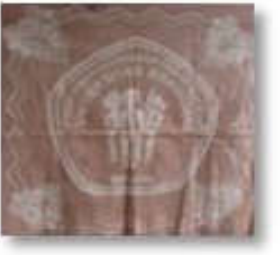

No Fixatives

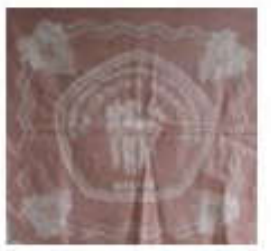

Lime

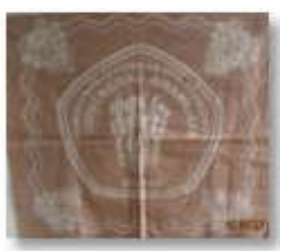

Alum

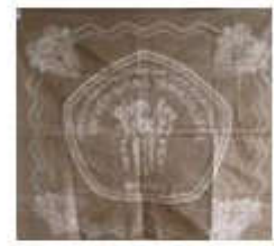

Iron

Figure 6 - Wind Drying

In wind drying, the fabric absorbs the dyestuff maximally so during rubbing and washing there has not been much do stain. According to Sulasmingsih (2006), the strong color durability against washing is associated with the occurrence of tannin bonds capable to get into the fabric fiber forming strong bond with fabric fibers. The addition of a fixative is able to lock and bind the absorbed dyestuff into the fiber material and produce different color 
changes such as alum $\left(\mathrm{Al}_{2}\left(\mathrm{SO}_{4}\right)_{3}\right) . \mathrm{Al}^{3+}$ and $\mathrm{Ca}^{2+}$ ions will cause ionic reactions between the ions with tannin so the natural dye molecules is inside the fiber becomes larger. This results in the dye molecule being difficult to get out of the pores of the fibers and strengthen color durability.

Consumers' Level of Preference. Consumers prefer batik cloth dyeing with natural colorant of coir of sun drying method with brownish red color and bright or light color. Consumers prefer sun drying and wind drying method with lime as the fixative. Consumers also prefer batik cloth with the logo of University of Brawijaya processed using sun drying with lime as the fixative. Consumers prefer bright batik cloth to dark batik cloth. The results of batik cloth using sun dried coir is presented in Figure 5, and using wind dried coir is presented in Figure 6.

\section{CONCLUSION}

The results of color intensity test show that alum as fixative, for both sun drying and wind drying method, has a higher $L^{*}$ value (27.65) compared to lime or iron as fixative. Lime as fixative can bind the red color with $a^{*}$ value of 24.13 and yellow color with $b^{*}$ value of 16.93. Color durability against rubbing and washing shows that lime as fixative has the best color durability. The best treatment is chosen using Multiple Attribute. The best treatment based on color intensity is sun drying with lime as fixative. The best treatment based on color durability is wind drying with lime as fixative.

\section{REFERENCES}

1. Aliya, 2010. Batik Pekalongan. Jakarta Timur: CV. Rama Edukasitama.

2. Alreza, Rahmad. 2012. Pengaruh Bahan Pelapis Terhadap Karakteristik Kelapa Muda Siap Saji Selama Penyimpanan. Skripsi. Fakultas Teknologi Pertanian. Institut Pertanian Bogor. Bogor

3. Astutik, Sri Mulia 2008. Teknik Pengeringan Bawang Merah Dengan Cara Perlakuan Suhu dan Tekanan Fakum. Teknik Pertanian, Vol. 13 No. 2

4. Atikasari, A. 2005. Kualitas Tahan luntur Warna Batik Cap di Griya Batik Larissa Pekalongan. Universitas Negeri Semarang Press. Semarang.

5. Blackwell, Wiley, 2012. Food Biochemistry and Food Processing, 2nd (ed). New York.

6. Failisnur \& Sofyan. 2014. Sifat tahan Luntur Dan Intensitas Warna Kain sutera Dengan Pewarna Alam Gambir (Uncaria gambir Roxb) Pada Kondisi Pencelupan Dan Jenis Fiksator Yang Berbeda. Jurnal Litbang Industri: 14 (1):1-8.

7. Farida, Iswartini, B. Gamal, Ruwanto, V. Atika \& Kamijana. 2011. Penelitian Zat Warna Alam Dari Rumput Laut Untuk Industri Batik. Balai Besar Kerajinan dan Batik Yogyakarta. Yogyakarta.

8. Hasanudin \& Widjiati. 2002. Penilaian Proses Pencelupan Zat Warna Soga Alam Pada Batik Kapas. Departemen Perindutsrian dan Perdagangan Republik Indonesia. Balai Besar Penelitian dan Pengembangan Industri Kerajinan Batik. Yogyakarta.

9. Herlina, S. 2007. Fiksasi Bahan Alami Buah Markisa dan Jeruk Nipis dalam Proses Pewarnaan Batik dengan Zat Warna Indigisol. Seni dan Budaya Yogyakarta. Yogyakarta.

10. Kristijanto, A., Soetjipto H. 2013. Pengaruh Jenis Fiksatif Terhadap Ketuaan dan Ketahanan Luntur Kain Mori Batik Hasil Pewarnaan Limbah Teh Hijau. Proceeding, Seminar Nasional Sains dan Pendidikan Sains VII, Fakultas Sains dan Matematika, Salatiga. Vol 4, No.1.

11. Manoi, F. 2006. Pengaruh Cara Pengeringan Terhadap Simplisia Mutu Sambiloto. Bul. Littro, Vol XVII: 1-5.

12. Manurang, M. 2012. Aplikasi Kulit Buah Manggis (Garcia mangostana L.) Sebagai Pewarna Alami Pada Kain Katun Secara Pre-Mordanting. Universitas Udayana. Bukit Jimbaran.

13. Mardiah. E. 1996. Penentuan Aktivitas dan Inhibisi Enzim Polifenol Oksidase dari Apel (Pyrus malus Linn). Jurnal Kimia Andalas, 2:2. 
14. Rahmawati, I. 2008. Penentuan Lama Pengeringan Pada Pembuatan Serbuk Biji Alpukat (Persea Americana mill). Unpublished Undergraduate Thesis. Faculty of Agricultural Technology. Universitas Brawijaya.

15. Sari, P., Agustina, F., Komar, M., Unus, Fauzi, M., \& T. Lindriati. 2005. Ekstraksi dan Stabilitas Antosianin Dari Kulit Buah Duwet (Syzygium cumini). Jurnal Teknologi dan Industri Pangan, XVI (2):102-108.

16. Sasas, K, Sunaryati, S, G Isminingsih, \& Santosa. 2000. Usaha Peningkatan Waste Kayu Bakau Sebagai Zat Warna Tekstil. Balai Besar Penelitian dan Pengembangan Industri Tekstil. Bandung.

17. Taofik, E., Yulianti, A. Barizi, E.K Hayati. 2010. Isolasi dan Identifikasi Senyawa Aktif Ekstrak Air Daun Paitan (Thitonia diversifolia) Sebagai Bahan Insektisida Botani Untuk Pengendalian Hama Tungau Eriophyidae. Universitas Maulana Malik Ibrahim. Malang.

18. Yusmeiarti. 2007. Penelitian Stabilisasi Dalam Penyimpanan Limbah Pengolahan Gambir Sebagai Pewarna Tekstil. Research Report, Balai Riset dan Standardisasi Industri Padang. 